\title{
ASSESSMENT OF THE ANTIFUNGAL ACTIVITY OF Spirulina platensis PHENOLIC EXTRACT AGAINST Aspergillus flavus
}

\author{
Avaliação da atividade antifúngica de extrato fenólico de \\ Spirulina platensis contra Aspergillus flavus \\ Michele Moraes de Souza1, Luciana Prietto², Anelise Christ Ribeiro², \\ Taiana Denardi de Souza², Eliana Badiale-Furlong²
}

\begin{abstract}
The production of safe food has stimulated the search for natural substances that possess antifungal activity. The indirect methods of estimating fungal biomass are based on the measurement of glucosamine, ergosterol and protein - typical compounds produced during the development of biomass. The aim of the study was to assess the effect of the phenolic extract from Spirulina platensis on the production of structural compounds in Aspergillus flavus, in order to identify its action on fungal inhibition. The Spirulina platensis methanolic extracts presented $1.15 \mathrm{mg}$ phenolic compound/g Spirulina platensis, which showed an antifungal effect against Aspergillus flavus, inhibiting the glucosamine production up to 56\%. Therefore, it may be employed as natural defense when food protection is necessary.
\end{abstract}

Index terms: Phenolic inhibitors, antifungal property, glucosamine, protein, ergosterol.

\section{RESUMO}

A produção de alimentos seguros tem estimulado a busca por substâncias naturais que possuem atividade antifúngica. Os métodos indiretos de estimativa de biomassa fúngica são baseados na medição de glucosamina, ergosterol e proteína - compostos típicos produzidos durante o desenvolvimento da biomassa. Neste estudo, objetivou-se avaliar o efeito do extrato fenólico de Spirulina platensis na produção de componentes estruturais em Aspergillus flavus, a fim de identificar seu mecanismo de ação dos fenóis na inibição fúngica. O extrato metanólico de Spirulina platensis apresentou 1,15 mg de compostos fenólicos/g Spirulina platensis, apresentando um efeito antifúngico contra Aspergillus flavus, inibindo a produção de glucosamina em até 56\%. Portanto, pode ser empregado como antifúngico natural quando for necessária a proteção de alimentos.

Termos para indexação: Inibidores fenólicos, propriedades antifúngicas, glucosamina, proteína, ergosterol.

(Received in august 29, 2011 and approved in october 31, 2011)

\section{INTRODUCTION}

Many common fungicides exhibit lower potency under field conditions and have been a source of chemical pollution, poisoning fruits and vegetables, which are essential to human diets (TANTAWY, 2011). Because of prolonged or overuse of some fungicides, many plant pathogens have developed resistance toward many synthetic chemicals, thereby rendering the fungicide ineffective (PÉRET-ALMEIDA et al., 2008; BELEWA et al., 2011; MEDEIROS et al., 2011).

Some species, e.g. Aspergillus flavus, are toxigenic and can contaminate food and produce mycotoxins among others (MEDEIROS et al., 2011).

Defensive chemical compounds are naturally present in several plants and microbial tissues: they comprise antibiotics, phenolic compounds, alkaloids, terpenes and proteins (HARUTA et al., 2001, HOLMES et al., 2008; OLIVEIRA; BADIALE-FURLONG, 2008; AHMADI et al., 2010; SOUZA et al., 2010). The structures of the phenolic compounds allow their diffusion through the microbial membrane and their penetration into the cell, where they can interfere in the metabolic pathways by hindering the synthesis of ergosterol, glucan, chitin, proteins and glucosamine in fungi, for example (BRUL; KLIS, 1999; MARINO et al., 2001). New studies of these compounds, their presence on a given type of tissue type and their mechanism of action are valid scientific contributions which may lead to the development of technologies that can employ them to produce food and medication.

The cyanobacterium Spirulina (Arthrospira) is used as food by humans because of its chemical composition, which has high quality and quantity of

'Universidade Federal do Rio Grande/FURG - Rua Alfredo Huch - 475 - Centro - Cx. P. 474 - $96201-900$ - Rio Grande - RS - Brasil michele.moraesdesouza@gmail.com

${ }^{2}$ Universidade Federal do Rio Grande/FURG - Rio Grande - RS - Brasil

Ciênc. agrotec., Lavras, v. 35, n. 6, p. 1050-1058, nov./dez., 2011 
proteins, essential amino acids, minerals, polyunsaturated fatty acids and vitamins. Furthermore, it has phenolic compounds (caffeic, chlorogenic, salicylic, synaptic and trans-cinnamic acids), tocopherol and pigments such as carotenoids, phycocyanin and chlorophyll, among its functional properties (PARISI et al., 2009).

Fungal pathogens are a major problem in agriculture, as most of the fungicides employed exhibit lower potency under field conditions and have been a source of chemical pollution, poisoning fruits and vegetables, which form an essential component of the human diet (TANTAWY, 2011). Some species, e.g. Aspergillus flavus, are toxigenic and can contaminate food and produce mycotoxins.

Many indirect methods have been described to assess fungal growth based on the measurements of certain components of the cell such as glucosamine, ergosterol, protein and nucleic acids, or the measurements of biological activity, such as respiration. However, all these indirect methods have limitations when it comes to estimating fungal biomass, because in each species, the chemical components are produced in a characteristic according to the life cycle of the microorganism.

Ergosterol, a sterol from the lipid class, is a component of fungal cell membranes, determinant of their fluidity (PEELER et al., 1989; DISCH et al., 1998). It is widely used to quantify living and active fungal biomass (GESSNER; CHAUVET, 1993; BEHALOVÁ et al., 1994). Glucosamine, a growth indicator, has the advantage of being present only in fungal cells of some genera (SPARRINGA; OWENS, 1999). This structure makes up the monomeric unit of the fungal cell wall (IKASARI, 2000) and it can be quantitatively estimated by depolymerization followed by the dosage of the released glucosamine. The level of glucosamine in fungi may vary according to the composition of the medium and the cultivation conditions (DESGRANGES et al., 1991; TOMASELLI-SCOTTI et al., 2001), but it is always present in the microbial structure.

The objective of study was to evaluate the effect of the extract from Spirulina platensis, on the production of structural components in Aspergillusflavus as indicators of antifungal activity. This research was carried out by characterizing the mechanistic action of the phenolic extract on the structural component of fungi cells in order to employ such microalgae extract as a natural antifungal source.

\section{MATERIAL AND METHODS}

\section{Spirulina platensis and preparation of phenolic extracts}

We used the cyanobacterium Spirulina strain isolated from Mangueira Lagoon and Mangueira Lagoon Water supplemented with $20 \%$ (v/v) Zarrouk medium (COSTA et al., 2002), referred to in the text as MLW-S medium, for maintenance, inoculum and biomass production. The pilot plant for production of Spirulina sp. was located near the shore of Mangueira Lagoon (33 $302133 \mathrm{~S} ; 53^{\circ} 082593 \mathrm{~W}$ ) and consisted of raceway tanks of different dimensions and volumes depending on their purpose. We used one inoculum tank $(4.0 \mathrm{~m}$ long $\times$ $1.0 \mathrm{~m}$ wide $\times 0.50 \mathrm{~m}$ high) with a surface area of $3.87 \mathrm{~m}^{2}$ and a working volume of $1000 \mathrm{~L}$ and three production tanks $(13.0 \mathrm{~m}$ long $\times 3.0 \mathrm{~m}$ wide $\times 0.50 \mathrm{~m}$ high), each with a surface area of $37.10 \mathrm{~m}^{2}$ and a working volume of $10,000 \mathrm{~L}$. All the tanks were lined with glass fiber and covered by a greenhouse structure constructed from transparent polyethylene film. All tank cultures were agitated by one paddle wheel rotating at $18 \mathrm{rpm} 24 \mathrm{~h}$ per day. The volume of culture media was maintained by the periodic addition of MLW to compensate for evaporation, about $12 \mathrm{l} / \mathrm{d}$, for tank of $10,000 \mathrm{~L}$, being added over the course of the experiment (MORAIS et al., 2009).

For extraction of phenolic compounds $2 \mathrm{~g}$ of Spirulina platensis was homogenized with $10 \mathrm{~mL}$ of methanol in an orbital shaker at $25^{\circ} \mathrm{C}$ for $60 \mathrm{~min}$ at $200 \mathrm{rpm}$. The agitation was interrupted at $15 \mathrm{~min}$, after which $10 \mathrm{~mL}$ of methanol was added and agitation was carried out for $60 \mathrm{~min}$. The extract was filtered and rinsed with $20 \mathrm{~mL}$ of hexane; this procedure was performed 3 times. The purified extract was evaporated in a rotary evaporator at $50^{\circ} \mathrm{C}$, dissolved in $25 \mathrm{~mL}$ of distilled water, and clarified with 5 $\mathrm{mL}$ of $0.1 \mathrm{M}$ barium hydroxide and $5 \mathrm{~mL}$ of $5 \%$ zinc sulfate.

Phenolic compounds (PC) in the extract were carried out by spectrophotometry using the Folin-Ciocalteau reagent and employing a calibration curve of gallic acid whose concentrations ranged from 2 to $30 \mathrm{mg} / \mathrm{ml}$ (SOUZA et al., 2009). The values of the PC in the samples were expressed in $\mathrm{mg}$ of phenols/g per sample.

\section{Microorganism}

The microorganism which was used in this study was the pathogenic fungi Aspergillus flavus CCT 1217. It was provided by the André Tosello Foundation collection, and grown on potato dextrose agar (PDA) at $24^{\circ} \mathrm{C}$ for 12 days until complete sporulation.

The spore suspension was obtained after propagation in a PDA medium, followed by extraction from 
the medium with $0.2 \%$ solution of tween 80 , filtration and enumeration of spores in a Neubauer chamber. The spore solution was standardized at $4 \times 10^{6}$ spores $/ \mathrm{mL}$.

\section{In vitro effect of the phenolic extracts on the fungal development}

The microorganism inhibition in the PC presence was studied in a PDA culture medium. The phenolic extract of Spirulina platensis was diluted directly in the autoclaved medium after cooling, and poured into Petri dishes $(9 \mathrm{~cm}$ in diameter). These procedures were carried out under aseptic conditions (laminar flow hood). The spore solution $(42 \mu \mathrm{L})$ containing $4 \times 10^{6}$ spores $/ \mathrm{mL}$ was added to the center of the plates. Incubation occurred in a growth chamber, at $24^{\circ}$ C for 21 days (OLIVEIRA et al., 2010).

The development of the fungus was estimated at 3 , $5,7,10,14$ and 21 days, with the control experiment as reference (a medium without any extract). The percentage of fungal inhibition (NGUEFACK et al, 2004) was calculated according to the formula described in Equation 1:

$$
\mathrm{I}=100 \mathrm{x}(\mathrm{C}-\mathrm{T}) / \mathrm{C}
$$

Where:

$\mathrm{I}=$ inhibition percentage

$\mathrm{C}=$ level of the fungal component in the control medium

$\mathrm{T}=$ level of the fungal component in the medium containing the inhibitor.

The growth of the fungal biomass, was stopped by freezing to $-18^{\circ} \mathrm{C}$ at the chosen intervals. Indicators of growth, i.e., dry mass, ergosterol, glucosamine and protein of the mycelium, were assessed by using Equation 1 to estimate the inhibition of each component.

\section{Determination of dry weight of mycelium}

Mycelium was separated from the medium by heat vacuum filtration and the dry mass was estimated after heating in an oven at $90^{\circ} \mathrm{C}$ until a constant weight was achieved. Each measurement was carried out threefold.

\section{Determination of the glucosamine}

The levels of glucosamine biomass were assessed by adding $5 \mathrm{~mL}$ of $\mathrm{HCl} 6 \mathrm{M}$ to $0.2 \mathrm{~g}$ of dry biomass followed by autoclaving at $121^{\circ} \mathrm{C}$ for 8 minutes. The mixture was cooled, filtered and collected in a $5 \mathrm{~mL}$ volumetric flask with distilled water. One $\mathrm{mL}$ of supernatant was transferred to a $25 \mathrm{~mL}$ volumetric flask, and a drop of alcoholic solution of phenolphthalein $(0.5 \% \mathrm{w} / \mathrm{v})$ was added, followed by neutralization with $3 \mathrm{M} \mathrm{NaOH}$ solution. The reverse titration was carried out with $\mathrm{KHSO}_{4} 1 \%$ (w/v) until the pink colour disappeared. The flask volume was completed with distilled water, and $1 \mathrm{~mL}$ of solution was transferred to test tubes, one $\mathrm{ml}$ of acetyl acetone in $50 \mathrm{~mL}$ of $\mathrm{Na}_{2} \mathrm{CO}_{3} 0.5 \mathrm{M}$ was also added, followed by heating in boiling water for $20 \mathrm{~min}$. After cooling, $6 \mathrm{~mL}$ of ethanol and $1 \mathrm{~mL}$ of Erlich's reagent (2.67 g DAB - p-dimethylaminobenzaldehyde (dissolved in $15 \mathrm{~mL}$ of ethanol and $15 \mathrm{~mL}$ of hydrochloric acid) were added. The tubes were incubated in an oven at $65^{\circ} \mathrm{C}$ for 10 minutes. The absorbance was read on a spectrophotometer at $530 \mathrm{~nm}$ and the glucosamine content was estimated by taking into account the absorptivity of the standard curve ranging from 1 to $25 \mu \mathrm{g} / \mathrm{mL}$. The recovery of the method was determined at fortification levels that ranged from 1 to $3 \mathrm{mg}$ of glucosamine per gram dry weight.

\section{Determination of the content of ergosterol}

The modified method of Gutarowska and Zakowska (2009) was used to determine the ergosterol content in the dry biomass and consisted of: $0.2 \mathrm{~g}$ of the samples with $10 \mathrm{~mL}$ of methanol agitated in shaker at 200 rpm for 30 minutes; this procedure was carried out threefold. The methanol extract was centrifuged at $3200 \mathrm{~g}$ at $20^{\circ} \mathrm{C}$ for $10 \mathrm{~min} ; 20 \mathrm{~mL}$ of $\mathrm{KOH} / \mathrm{methanol} \mathrm{were} \mathrm{added} \mathrm{to}$ the supernatant, which was then heated under reflux for $30 \mathrm{~min}$ and cooled to $4^{\circ} \mathrm{C}$. The refluxed material was submitted to four partitions with $20 \mathrm{~mL}$ hexane. The hexane fraction was dried in a rotary evaporator at $60^{\circ} \mathrm{C}$. The residue was dissolved with $10 \mathrm{~mL}$ methanol and the transmittance was determined at $283 \mathrm{~nm}$. The ergosterol content was estimated using a calibration curve of standard ergosterol whose concentrations ranged from 1.5 to $16.5 \mu \mathrm{g} / \mathrm{mL}$. The ergosterol content was expressed in milligrams per gram of dry biomass.

\section{Measurement of proteins}

Fungal biomass protein levels were estimated by the micro-Kjeldahl method (AOAC, 2000), using 6.25 as the nitrogen conversion factor.

\section{Statistical analysis}

The results obtained by the antifungal activity tests were assessed by comparing the means of development over time in the fungal absence and presence of PC by using the Tukey test. Differences were considered significant when $\mathrm{p}<0.05$.

\section{RESULTSAND DISCUSSION}

Several types of solvents are commonly used to extract phenolic compounds from plant and microbial 
matrices: water, ethyl acetate, methanol, ethanol, acetone and hexane. In general, hexane removes carotenoids and chlorophyll, methanol extracts sugars, organic acids and low molecular weight phenols and ethyl acetate extracts only the low molecular weight phenols (MOURE et al., 2001; ROBARDS, 2003; SKERGET et al., 2005; TANTAWY, 2011).

Based on previous results this study adopted methanolic extraction and quantification of total phenolic compounds (SOUZA et al., 2009). The recovery in the solvent system (methanol) used in this study was higher than $85 \%$ and the content found in the microalga was $1.15 \pm 0.13 \mathrm{mg} / \mathrm{g}$ In this sample, the extraction of PC with hexan and ethyl acetic extracts showed low levels of reactive compounds with Folin-Ciocalteau reagent, $0.37 \pm 0.07$ and $0.31 \pm 0.09 \mathrm{mg} / \mathrm{g}$ respectively, when compared with the methanolic extract, possibly because in these fractions, the PC with low molecular weight (such as formononetin and pinocembrin) are very small compared with the ones that are present in the methanolic fraction which contain organic acids such as caffeic, chlorogenic, salicylic, synaptic and transcinnamic acid with a higher antioxidant potential (COLLA et al., 2007).

The Spirulina platensis is a promising source of PC when compared with other plant tissues mentioned in the literature, such as banana $(0.31 \mathrm{mg} / \mathrm{g})$, potato $(1 \mathrm{mg} /$ g), polished rice (0.06 to $0.08 \mathrm{mg} / \mathrm{g}$ ) (ZHOU et al., 2004), orange peel $(0.69 \mathrm{mg} / \mathrm{g})$ and eggplant pulp $(0.35 \mathrm{mg} / \mathrm{g})$ (OLIVEIRA et al., 2007). The same happens when compared with other microalgae, such as Crypthecodinium cohnii ( 0.36 and $0.37 \mathrm{mg} / \mathrm{g})$, Nostoc ellipsosporum $(0.08$ and $0.40 \mathrm{mg} / \mathrm{g})$, Schizochytrium sp. (0.12 and $0.16 \mathrm{mg} / \mathrm{g}$ ) and Thraustochytrium sp., (0.01 and $0.26 \mathrm{mg} / \mathrm{g}$ ) all in the hexanic and ethyl acetatic fraction, respectively (HUA-BIN et al., 2007).

PC extracted from Spirulina platensis were tested regarding their potential to inhibit Aspergillus flavus biomass development, the indicators of which were the levels of glucosamine, ergosterol and protein. The aim was to identify the effect of extracts in the different fungal structures components.

The Spirulina platensis PC antifungal activity was examined by testing its different concentrations in the culture medium in order to determine the lowest inhibitory concentration, and this value was $54 \mu \mathrm{g} / \mathrm{mL}$ of the culture medium. Parisi et al., (2009) found $47.5 \mathrm{mg} / \mathrm{mL}$ as the Spirulina platensis phenolic extract minimum inhibitory concentration against Staphylococus aureus. Methanolic extracts obtained from pennyroyal (Mentha pulegium L.), taro (Xanthosema violaceum) and jambolão (Syzygium cuminii L.) showed that these plants require, respectively, 200, 50 and $60 \mathrm{mg} / \mathrm{mL}$ of extract to inhibit the Staphylococus aureus development in the agar diffusion test (MICHELIN et al., 2005). In the literature, there are only reports of phenolic compounds from microalgae inhibition against bacteria growth. This fact makes it difficult to compare results regarding the effects of phenolic compounds from Spirulina platensis in fungal development, and turn these results into new information.

The levels of dry fungal biomass produced during the control experiments and in the presence of PC extracted from Spirulina platensis are shown in Table 1. The velocities of development are shown in Figure 1.

In each experiment interval, the dry mass of Aspergillus flavus was on average four times lower than the control experiment, indicating that the fungal growth was inhibited by the addition of the phenolic compound from Spirulina platensis. Figure 1 also shows low Aspergillus flavus biomass growth rate in the presence of the PC, with a better correlation and linearity than the biomass development control curve, $\mathrm{R}^{2}=0.861$ and $\mathrm{R}^{2}=$ 0.693, respectively. Souza et al. (2010) tested the Rhyzopus oryzae growth in the presence of PC from Chlorella sp., but there was no significant inhibition by this source. The levels of glucosamine, protein and ergosterol determin of the study period are presented in Table 2 .

Table 1 -Aspergillus flavus fungal biomass (grams) during the experiments.

\begin{tabular}{ccccccc}
\hline & \multicolumn{7}{c}{ Days } & & \\
\cline { 2 - 6 } Extracts & $3^{\mathrm{o}}$ & $5^{\mathrm{o}}$ & $7^{\mathrm{o}}$ & $10^{\mathrm{o}}$ & $14^{\mathrm{o}}$ & $21^{\mathrm{o}}$ \\
\hline Control & $0.10^{\mathrm{a}, \mathrm{A}}$ & $0.30^{\mathrm{b}, \mathrm{C}}$ & $0.70^{\mathrm{c}, \mathrm{D}}$ & $0.72^{\mathrm{c}, \mathrm{D}}$ & $0.86^{\mathrm{d}, \mathrm{F}}$ & $0.91^{\mathrm{d}, \mathrm{F}}$ \\
Treatment & $0.01^{\mathrm{a}, \mathrm{B}}$ & $0.07^{\mathrm{b}, \mathrm{A}}$ & $0.12^{\mathrm{c}, \mathrm{A}}$ & $0.43^{\mathrm{d}, \mathrm{E}}$ & $0.44^{\mathrm{d}, \mathrm{G}}$ & $0.52^{\mathrm{d}, \mathrm{H}}$ \\
\hline
\end{tabular}

Lower case letters in the same line are not statistically different from the control $(\mathrm{p}<0.05)$ for each biomass. Upper case letters in the same column are not statistically different from the control $(\mathrm{p}<0.05)$ for each day. 


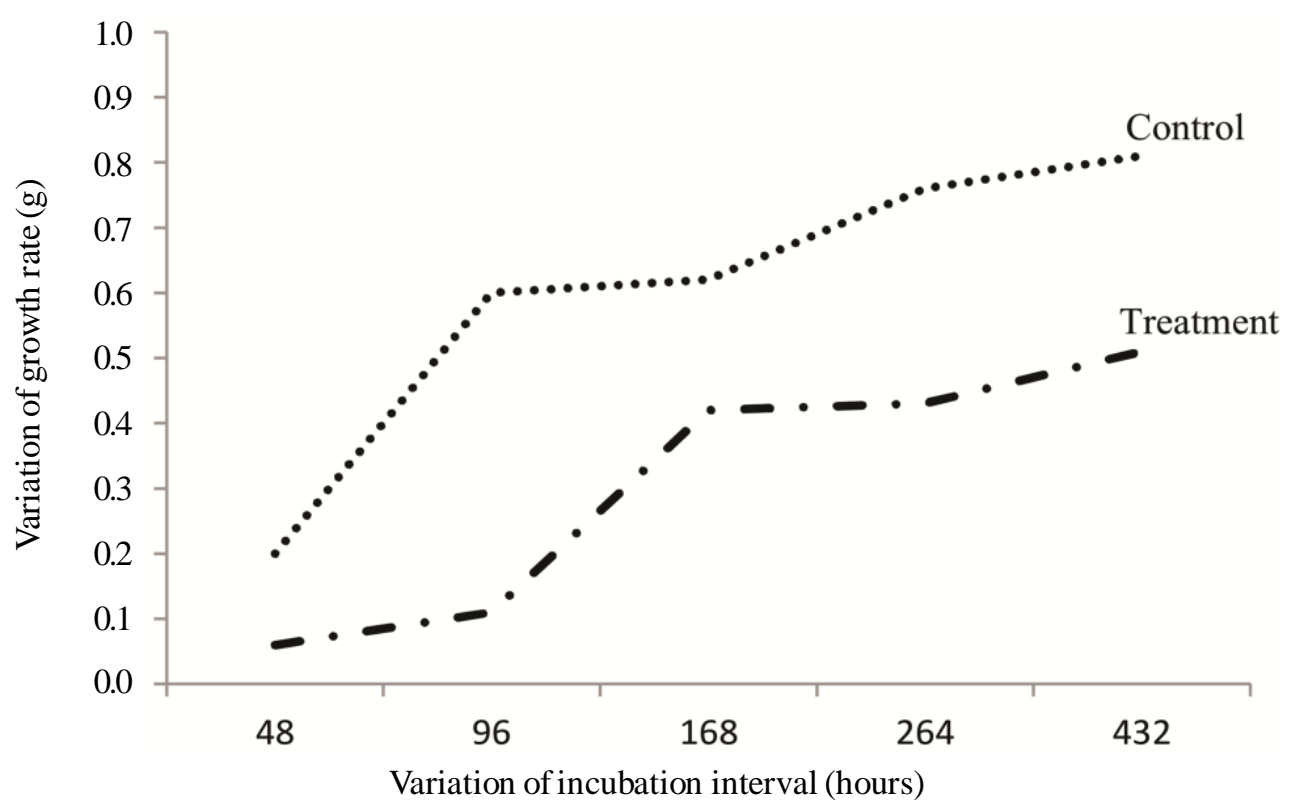

Figure 1 - Variation of the Aspergillus flavus biomass growth rate in the absence and presence of the PC.

Table 2 - Fungal biomass components during the experiments.

\begin{tabular}{ccccccc}
\hline Period (day) & \multicolumn{2}{c}{ Glucosamine $(\mathrm{mg} / \mathrm{g})$} & \multicolumn{2}{c}{ Ergosterol $(\mathrm{mg} / \mathrm{g})$} & \multicolumn{2}{c}{ Protein $(\mathrm{mg} / \mathrm{g})$} \\
& Control & Treatment & Control & Treatment & Control & Treatment \\
\hline $3^{\mathrm{o}}$ & nd & nd & nd & nd & nd & nd \\
$5^{\mathrm{o}}$ & $21.2^{\mathrm{a}, \mathrm{A}}$ & $9.3^{\mathrm{a}, \mathrm{B}}$ & $3.0^{\mathrm{a}, \mathrm{A}}$ & $2.2^{\mathrm{a}, \mathrm{B}}$ & $244^{\mathrm{a}, \mathrm{A}}$ & $156^{\mathrm{a}, \mathrm{B}}$ \\
$7^{\circ}$ & $23.9^{\mathrm{a}, \mathrm{A}}$ & $17.1^{\mathrm{b}, \mathrm{C}}$ & $3.1^{\mathrm{a}, \mathrm{A}}$ & $2.4^{\mathrm{a}, \mathrm{B}}$ & $217^{\mathrm{b}, \mathrm{C}}$ & $151^{\mathrm{a}, \mathrm{D}}$ \\
$10^{\circ}$ & $24.1^{\mathrm{a}, \mathrm{A}}$ & $17.8^{\mathrm{b}, \mathrm{C}}$ & $2.8^{\mathrm{b}, \mathrm{B}}$ & $2.2^{\mathrm{a}, \mathrm{B}}$ & $221^{\mathrm{b}, \mathrm{C}}$ & $195^{\mathrm{b}, \mathrm{E}}$ \\
$14^{\circ}$ & $27.2^{\mathrm{b}, \mathrm{D}}$ & $19^{\mathrm{b}, \mathrm{E}}$ & $3.0^{\mathrm{a}, \mathrm{C}}$ & $2.4^{\mathrm{a}, \mathrm{B}}$ & $283^{\mathrm{c}, \mathrm{F}}$ & $237^{\mathrm{c}, \mathrm{G}}$ \\
$21^{\circ}$ & $32^{\mathrm{c}, \mathrm{F}}$ & $22^{\mathrm{c}, \mathrm{G}}$ & $2.8^{\mathrm{b}, \mathrm{C}}$ & $2.4^{\mathrm{a}, \mathrm{B}}$ & $291^{\mathrm{d}, \mathrm{H}}$ & $301^{\mathrm{d}, \mathrm{H}}$ \\
\hline
\end{tabular}

Lower case letters in the same line are not statistically different from the control $(\mathrm{p}<0.05)$ for each cellular component. Upper case letters in the same column are not statistically different from the control $(\mathrm{p}<0.05)$ for each cellular component.

On the $3^{\text {rd }}$ day of the experiment it was not possible to measure the glucosamine, protein and ergosterol contents in any experiment, because the fungal biomass was below the required level for extraction. Subsequently, the mean values of glucosamine, ergosterol and protein content in the presence of PC were 1.6, 1.2 and 1.3 times, respectively, lower than the control group, respectively, during the 21-day experiment.

These values represent a significant glucosamine inhibition at the $95 \%$ level of confidence. The increase in the glucosamine level in the control group was similar to the one obtained by Desgranges et al. (1991) in Beauveria bassiana cultivation, by Gelmi et al. (2000) in Gibberella fujikuroi cultivation and by Nopharatana et al. (2003) in Rhizopus oligosporus cultivation. However, it was different from the increase found in the case of Thermoascus aurantiacus in which the glucosamine content remained constant over the period of the study.

Nagel et al. (2001) used glucosamine as Aspergillus oryzae growth indicator on wheat grains by using an empirical equation generated from the glucosamine production by the biomass cultivated in a conventional medium. They verified that the glucosamine content increased in a similar way to the results found in this study with Aspergillus flavus. Ooijkaas et al. (1998) also found an increase in the Coniothyrium minitans glucosamine 
content grown on Petri dishes, over the cultivation time. It is worth pointing out that the glucosamine method is also the most common one to quantify fungal biomass in solid state fermentation.

According to Cowan (1999), the antimicrobial activity of the phenolic substances may be linked to their ability to make the bacterial extracellular protein layer more complex.

The same indicator of wall polymer inhibition was observed in this study. However, in the presence of Spirulina platensis PC extracts, there was no significant inhibition (95\% confidence) of the ergosterol content produced throughout the period of the study. This fact suggests that the ergosterol might not be a good indicator to monitor the Aspergillus flavus biomass development because it remained relatively constant in the control and in the culture with PC, indicating that they did not affect the membrane components, as was mentioned by Behalová et al.(1994), Barajas-Aceves et al. (2002), Gutarowska and Zakowska, (2009). Figure 2 shows the percentage of fungal inhibition by the phenolic extract from Spirulina platensis in each component under evaluation.

The presence of PC in the culture medium did not affect the protein production during the incubation period. It should be pointed out that the inhibition percentage of glucosamine was on average two fold higher than the ergosterol and the protein inhibition.
Even though the fungal biomass protein content was affected by the phenolic extract, it was not the most representative component of the fungal development because it had an unstable pattern of production over time, it was estimated by using the factor 6.25 , which is not specific for fungal species. This fact may be related to the protein content overestimation since the actual glucosamine could interfere in the determination because it is a nitrogenated carbohydrate.

Kaushik and Chauhan (2008) reported that extracts from Spirulina platensis inhibited the development of Staphylococcus aureus (S.aureus), Escherichia coli (E.coli) P. aeruginosa, S. typhi, and K. pneumoniae. The authors used hexane, ethyl acetate, dichloromethane and methanol to obtain the phenolic extracts, and the methanolic extracts had the best results. The methanolic extract of $S$. aureus and $E$. coli minimum inhibitory concentrations (MIC) were $128 \mu \mathrm{g} / \mathrm{mL}$ and $256 \mu \mathrm{g} / \mathrm{mL}$, respectively. Parisi et al. (2009) also found high antimicrobial activity of phenolic compounds extracted with methanol from Spirulina platensis against S.aureus. However, no reports on antifungal tests using phenolic compounds extracted from Spirulina platensis were found, although the results - regarding inhibition - obtained for a toxigenic species, such as the one reported here, were promising in terms of preventing the development of the cell wall microorganism.

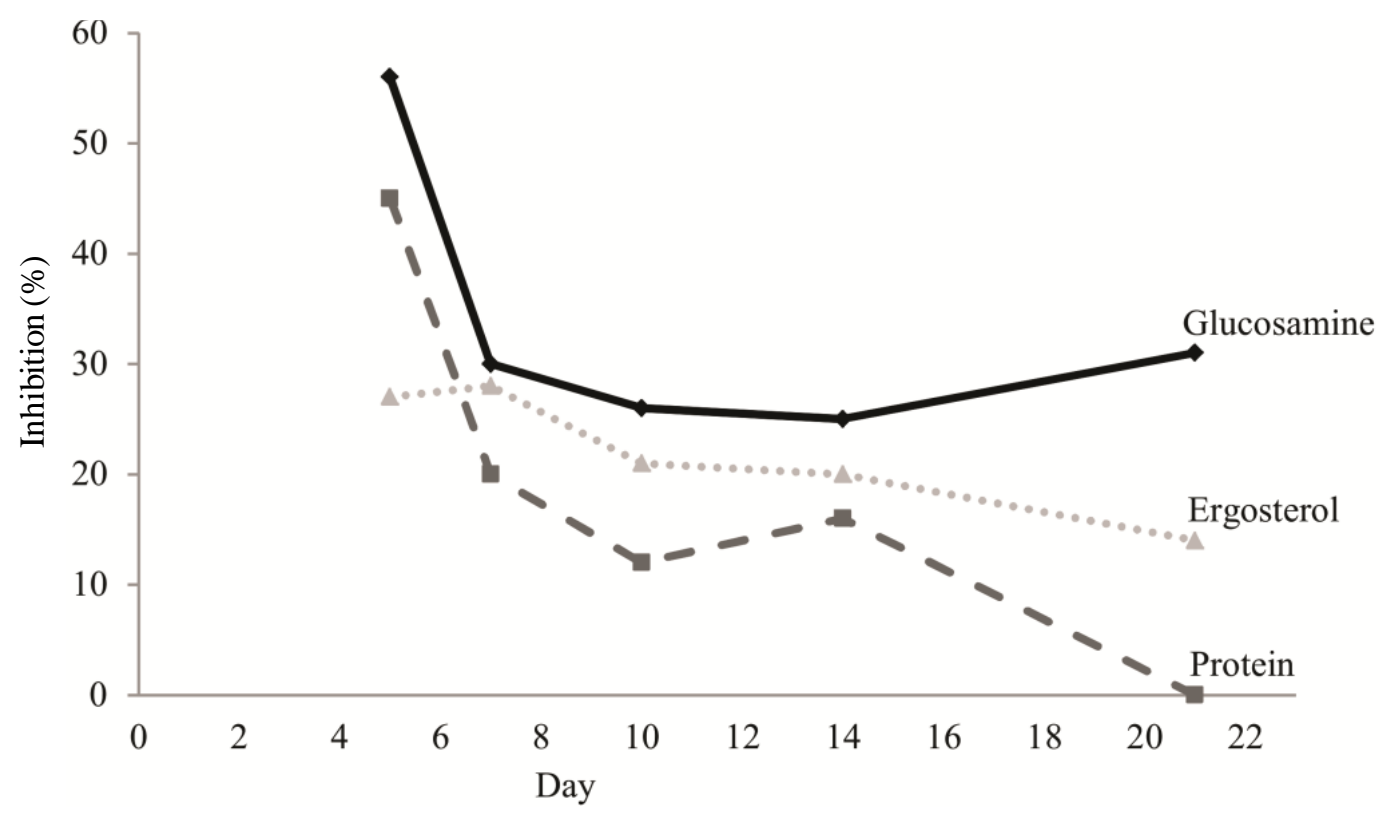

Figure 2 - Fungal inhibition by Spirulina platensis phenolic extract. 


\section{CONCLUSION}

The glucosamine content in fungal biomass is the most suitable to investigate the effect of Spirulina platensis extracts on the fungal biomass development, because its production was linear along the time in the control experiment and is the most affected by the PC in the culture medium. The phenolic extract from Spirulina platensis showed antifungal activity, by inhibiting the glucosamine production up to $56 \%$.

\section{ACKNOWLEDGMENTS}

The authors are grateful to CAPES, FAPERGS and CNPq.

\section{REFERENCES}

AHMADI, F. et al. Chemical composition, in vitro antimicrobial, antifungal and antioxidant activities of the essential oil and methanolic extract of Hymenocrater longiflorus of Iran. Food and Chemistry and Toxicology, Richmond, v. 48, p. 1137-1144, 2010.

AOAC. Association of Official Analytical Chemists. Official Methods of analysis international, 17 th, CDROM, Willian Horwitz, 2000.

BARAJAS-ACEVES, M. et al. Effect of pollutants on the ergosterol content as indicator of fungal biomass.

Journal of Microbiological Methods, Amsterdam, v.50, p.227-236, 2002.

BEHALOVÁ, B.; BLÁHOVA, M.; BEHAL, V. Regulation of sterolbiosynthesis in Saccharomyces cerevisiae. Food Microbiology, London. v.39, p.287-290, 1994.

BELEWA, V.; BAIJNATH, H.; SOMAI, B.M. Aqueous extracts from the bulbs of Tulbaghia violacea are antifungal against Aspergillus flavus. Journal of Food Safety, v.31, n.2, p.176-184, 2011.

BRUL, S.; KLIS, F. M. Mechanistic and Mathematical inactivation studies of food spoilage fungi. Fungal genetics and biology, Orlando, v.27, p.199-208, 1999.

COLLA, L. M.; BADIALE-FURLONG, E.; COSTA, J.A.V. Antioxidant properties of Spirulina (Arthrospira) platensis cultivated under different temperatures and nitrogen regimes. Brazilian Archives of Biology and Technology, Curitiba, v.50, n.1, p.161-167, 2007.
COSTA, J.A.V. et al. Modelling of Spirulina platensis growth in fresh water using response surface methodology. World Journal of Microbiology and Biotechnology, v.18, p.603-607, 2002.

COSTA, J.A.V.; COLLA, L.M.; DUARTE, P.F. Improving Spirulina platensis biomass yield a fedbatch process. Bioresource Technology, New York, v.92, p.237-241, 2004.

COWAN, M. M. Plant products as antimicrobial agents. Clinical Microbiology Reviews, Washington, v.12, p.564-582, 1999.

DESGRANGES, C. et al. Biomass estimation in solid state fermentation. Applied Microbiology and Biotechnology, Berlin, v. 35, p.200-205, 1991.

DISCH, A. et al. Distribution of the mevalonate and glyceraldehyde phosphate/pyruvate pathways for isoprenoid biosynthesis in unicellular algae and the cyanobacterium Synechocystis PCC 6714.

Biochemistry, Washington, v.30, p.427-433, 1998.

GELMI C. et al. Solid substrate cultivation of Gibberella fujikuroi on an inert support. Process Biochemistry, London, v.35, p.1227-1233, 2000.

GESSNER, M.O.; E. CHAUVET, E. Ergosterol-tobiomass conversion factors for aquatic hyphomycetes. Applied and Environmental Microbiology, Washington, v.59, p.502-507, 1993.

GUTAROWSKA, B.; ZAKOWSKA, Z. Mathematical models of mycelium growth and ergosterol synthesis in stationary mould culture. Letters in Applied Microbiology, Oxford, v.48, p.605-610, 2009.

HARUTA, M. et al. A Kunits trypsin inhibitor gene family from trembling aspen (Populus tremuloides Michx.): clonning, functional expression, and induction bywounding and herbivory. Plant Molecular Biology, Dordrecht, v.46, p.347-359, 2001.

HOLMES, R.A.; BOSTON, R.S.; PAYNE, G.A. Diverse inhibitors of aflatoxin biosynthesis. Applied

Microbiology and Biotechnology, Berlin, v.78, p.559$572,2008$. 
HUA-BIN, L. et al. Evaluation of antioxidant capacity and total phenolic content of different fractions of selected microalgae. Food Chemistry, Barking, v.102, p.771-776, 2007.

IKASARI, L.; MITCHELL, D.A. Two-Phase Model of the Kinetics of Growth of Rhizopus oligosporus in Membrane Culture. Biotechnology and Bioengineering, New York, v.68, p.619-627, 2000.

KAUSHIK, P.; CHAUHAN, A. In vitro antibacterial activity of laboratory grown culture of Spirulina platensis. Indian Journal of Medical Microbiology, v.48, p.348-52, 2008.

MARINO, M.; BERSANI, C.; COMI, G. Impedance measurements to study the antimicrobial activity of essential oils from Lamiaceae and Compositae, International Journal of Food Science \& Technology, Oxford, v. 67, p.187-195, 2001.

MEDEIROS, R.T.S.; GONÇALEZ, E.; FELICIO, R. C.; FELICIO, J. D. Evaluation of antifungal activity of Pittosporum undulatum L. essential oil against Aspergillus flavus and aflatoxin production. Ciência e Agrotecnologia, Lavras, v.35, n.1, p.71-76, 2011.

MICHELIN, D. C. et al. Avaliação da atividade antimicrobiana de extratos vegetais. Revista Brasileira de Farmacognosia, Curitiba, v.15, n.4, p.316-20, out./dez. 2005.

MORAIS, M. G. et al. Pilot scale semicontinuous production of Spirulina biomass in southern Brazil. Aquaculture, London, v.294, p. 60-64, 2009.

MOURE, A.; et al. Natural antioxidants from residual sources (Review). Food Chemistry, Barking, v.72, p.145$171,2001$.

NAGEL, F. J. I. et al. Temperature control in a continuously mixed bioreactor for solid-state Fermentation. Biotechnology and Bioengineering, New York, v.72, p.219-230, 2001.

NGUEFACK, J. et al. Evaluation of five essential oils from aromatic plants of Cameroon for controlling food spoilage and mycotoxin producing fungi. International Journal of Food Microbiology, Grugliasco, v. 94, p. 329$334,2004$.
NOPHARATANA, M.; MITCHELL, D. A.; HOWES, T. Use of confocal microscopy to follow the development of penetrative hyphae during growth of Rhizopus oligosporus in an artificial solid-state fermentation System. Biotechnology \& Bioengineering, New York, v.81, p.438-447, 2003.

OLIVEIRA, M.S.; BADIALE-FURLONG, E. Screening of antifungal and antimycotoxigenic activity of plant phenolic extracts. World Mycotoxin Journal, v.1, p.1-10, 2008.

OLIVEIRA, M. S. et al. Atividade antioxidante e antifúngica de extratos vegetais. Revista Alimentos e Nutrição, Araraquara, v.18, n.3, p. 267-275, jul./set, 2007.

OLIVEIRA, M.S.; FEDDERN, V.; KUPSKI, L.; CIPOLATTI, E.; BADIALE-FURLONG E.; SOUZASOARES, L. A. Physico-chemical characterization of fermented Rice bran biomass. Ciencia y Tecnologia Alimentaria, Reynosa, v.8, p.229-236, 2010.

OOIJKAAS, L. P.; TRAMPER, J.; BUITELAAR, R. M. Biomass estimation of Coniothyrium minitans in solidstate fermentation. Enzyme and Microbial Technology, New York, v.22, p.480-486, 1998.

PÉRET-ALMEIDA, L.; NAGHETINI, C.C.; NUNAN, E.A.; JUNQUEIRA, R.G.; GLÓRIAS, M.B.A. Atividade antimicrobiana in vitro do rizoma em pó, dos pigmentos curcuminóides e dos óleos essenciais da Curcuma Longa L. Ciência e Agrotecnologia, Lavras, v.32, n.3, p.875-881, 2008.

PARISI, A.S.; YOUNES, S.; REINEHR, C. O.; COLLA, L. M. Assessment of the antibacterial activity of microalgae Spirulina platensis. Revista de Ciências

Farmacêuticas Básica e Aplicada, Araraquara, v.30, n.3, p. 97-301, 2009.

PEELER, T. C. et al. Lipid Chracterization of an enriched plasma membrane fraction of Dunaliella salina Grown in media of varying salinity. Plant Physiology, Lancaster, v.89, p. 970-976, 1989.

ROBARDS, K. Strategies for the determination of bioactive phenols in plants, fruit and vegetables (Review). Journal of Chromatography A, New York, v.1000, p.657-691, 2003. 
SKERGET, M. et al. Phenols, proanthocyanidins, flavones and flavonols in some plant materials and their antioxidant activities. Food Chemistry, Barking, v.89, p.191-198, 2005.

SOUZA, M. M. et al. Antifungal activity evaluation in phenolic extracts from onion, rice bran, and Chlorella phyrenoidosa Ciência e Tecnologia de Alimentos, Campinas, v.30, n.3, p.680-685, jul/set, 2010.

SOUZA, M. M. et al. Study on the extracting conditions of phenolic compounds from onion (Allium cepa L.). Revista do Instituto Adolf Lutz, São Paulo, v.68, n.2, p.192-200, 2009.

SPARRINGA, R.A.; OWENS, J.D. Glucosamine content of tempe mould, Rhizopus oligosporus. International
Journal of Food Microbiology, Amsterdam v.47, p.153$157,1999$.

TANTAWY, S. T.A. Biological potential of cyanobacterial metabolites against some soil pathogenic fungi. Journal of Food, Agriculture \& Environment, v.9, n. 1, p. $663-666,2011$.

TOMASELLI-SCOTTI, C. et al. Glucosamine measurement as indirect method for biomass estimation of Cunninghamella elegans grown in solid state cultivation conditions. Biochemical Engineering Journal, Amsterdam, v.7, p.1-5, 2001.

ZHOU, Z. et al. The distribution of phenolic acids in rice. Food Chemistry, Barking, v.87, p.401-406, 2004. 